\title{
Role of Secretory Excretory Products of Schistosoma Mansoni Eggs in Modulating Hepatic Morbidity
}

\author{
Ibrahim Rabia; Zeinab Fahmy, Eman El-Ahwany ${ }^{*}$ and Hoda Sabry \\ Parasitology, Immunology* Departments Theoder Bilharz Research Insitute, \\ Giza ,Egypt
}

\begin{abstract}
In the present study the possible anti-morbidity effect of secretory excretory products (SEP) of Schistoma mansoni eggs (given to mice before infection) was investigated. Multiple small doses of SEP were injected intra-peritoneally into albino mice $(100 \mu \mathrm{g}$ of purified SEP followed 2 weeks later by two booster doses of $50 \mu \mathrm{g}$ each at weekly intervals). Data revealed reduction in CD4+ cells and increase in CD8+ cells of hepatic granuloma in SEP-immunized infected group, resulting in significant decrease in CD4+/CD8+ ratio, in comparison to infected control group. The serum cytokine level of both TNF--alpha and IFN-gamma were also significantly decreased. Histopathological examination of liver revealed remarkable increase in degenerated ova within hepatic granuloma which decreased in diameter (12\%). Significant reduction in worm burden $(46 \%)$ and tissue egg loads $(42.8 \%$ and $50 \%$ for hepatic and intestinal ova respectively) were observed. Mean while decreased percent of immature stages with increase in percent of dead ova in Oogram pattern was recorded. This work may help in decrease the severity of hepatic morbidity.
\end{abstract}

\section{Introduction}

Schistosomiasis mansoni is a tropical helminthic disease characterized by parasite egg-induced granulomatous inflammation and cumulative fibrosis. In a previous study, Boros (1989) told that the small granuloma size could lessen the possibility of tissue damage. At the same time, regulation of the host reaction to Schistosome egg antigen (SEA) by induction of specific T-cell unrespon-siveness could be potent prophylactic measure to prevent excessive destruction of host tissues by the granulomatous inflammation characteristic of acute schistosomiasis Stadecker (1992).

Recently, a variety of secretoryexcretory products, from different stages of S.mansoni, have been identified to induce a level of host-protective immune responses with amelioration of morbidity (Maher et al., 2003; El-Ahwany et al., 2006).

Parasitic helminthes secrete or excrete a variety of molecules (SEP) into their mammalian host' in some host- parasite systems, SEP may induce host-protective immune responses and their source of protective antigens has been utilized in successful vaccination model against helminthic infection (Lightowlers and Rickards, 1988). In infection with $S$. mansoni, hepatic granuloma formation is mediated by CD4+ $\mathrm{T}$ lymphocytes sensitized to egg antigens (Singh et al., 2004). The systematic identification of immunogenic egg components is important to understand the specific basis of egginduced immuno-pathology in schistosomiasis. To gain further insight into the specific immune response against parasite eggs, Asahi et al. (2003), characterized several egg antigens with a molecular weight of $25 \mathrm{kDa}(\mathrm{Sm}-\mathrm{p} 25)$. They added that a recombinant Sm-p25 protein elicited significant proliferative and cytokine responses in addition to induced antibody responses. higher level of antibodies were detected in infected sera obtained after parasite oviposition. Doenhoff et al.(2003), reported that a $27 \mathrm{kDa}$ enzyme secreted by $S$. mansoni eggs is presumed to be responsible for the Schistosome egg fibrinolytic activity.

Several promising trials in experimental models of protective immunity in schistosomiasis have identified. (Pearce et 
al., 1988 , Wolwezuk et al., 1989 , Botros et al., 1995, Hassanein et al., 1997 and Hassanein et al 1999). At the sametime , an approach aims to identify proteins from Schistosoma mansoni that are capable of stimulating protective Th1 cell-mediated immune responses was considered (Mountford and Harrop 1998).

The present study was designed to investigate the response to injection of purified secretory excretory products (SEP) of $S$. mansoni eggs prior to infection with $S$. mansoni cercariae as an experimental trial to decreasing or modulating severe hepatic morbidity.

\section{Materials and Methods}

\section{A- Animals}

1- The animals were supplied and housed throughout the study in the Schistosome Biological Supply Center (SBSP), at Theodor Bilharz Research Institute (TBRI), an institution responsible for animal ethics.

Laboratory bred male albino mice of CDI strain, weighing 18-20 grams were used. Experimental animals were kept in air conditioned rooms at $25{ }^{\circ} \mathrm{C}$, receiving food containing $24 \%$ protein.

2- Schistosoma mansoni cercariae were obtained from (SBSP) at (TBRI) and infection was performed by subcutaneous injection of $100 \mathrm{~S}$. mansoni cercariae to each mouse (Liang et al., 1987).

3- Schistosome eggs were isolated according to Von Lichtenberg, (1962) from the liver of 8 weeks previously infected mice received 120 cercariae of $S$. mansoni. Eggs were suspended in normal saline $(0.9 / \mathrm{L})$ and put in culture medium containing RPMI-1640 (Sigma Chemical Co, St. Louis, USA) supplemented with antibiotics $(300 \mathrm{IU} / \mathrm{ml}$ penicillin, $300 \mathrm{ug} / \mathrm{ml}$ streptomycin and $160 \mathrm{ug} / \mathrm{ml}$ gentamycin). All the steps of cultivation were done under sterile conditions .About $6000 \mathrm{eggs} / 5 \mathrm{ml}$ of culture medium were incubated for 1-3 days at $37{ }^{\circ} \mathrm{C}$ in $5 \% \mathrm{CO} 2$ incubator, $\mathrm{pH}$ was adjusted to 7.5 by adding $0.1 \mathrm{~N}$ $\mathrm{NaOH}$.
The total culture medium containing secretory / excretory products of eggs was concentrated and purified using ammonium sulfate precipitation method according to (Jaton et al., 1979). Protein content was measured using Bio-Rad method, sterilized, fractionated and stored at $-70{ }^{\circ} \mathrm{C}$ until used. The antigenicity of SEP was tested using ELISA test (Bradford, 1976).

\section{B- Experimental design:}

Experimental animals were divided into 3 groups, each groups of 15 individual. Group (1): SEP immunized group:

Each mouse was injected intraperitoneally with $100 \mu \mathrm{g} / \mathrm{ml}$ of secretoryexcretory products (SEP) emulsified with complete Freunds' adjuvant. Animals were boosted two weeks later with $50 \mathrm{ug} / \mathrm{ml}$ of SEP emulsified with incomplete Freund's adjuvant and boosted again one week apart. the mice were sacrificed 8 weeks following last dose of SEP.

Group II: - Each mouse was injected intraperitoneally with $100 \mu \mathrm{g} / \mathrm{ml}$ of SEP of egg antigen emulsified with complete Freunds' adjuvant. Then, the animals were boosted after two weeks with $50 \mu \mathrm{g}$ of SEP emulsified with incomplete Freund's adjuvant. Again, after one week, the animals were boosted with $50 \mu \mathrm{g}$ of SEP emulsified with incomplete Freund's adjuvant. Mice were infected with 100 S. mansoni cecariae, one week after last immunization by sub-cutaneous injection and the mice were sacrificed 8 weeks post-infection.

Group III: Shistosoma mansoni infected control group, animals were infected sub-cutaneously with 100 cercariae and sacrificed 8 weeks later.

\section{C- Parasitological parameters:}

1- Worm burden: Perfusion of adult worms from the liver and porto-mesenteric system was performed 8 weeks after infection according to Duvall and Dewitt (1967).

2- Tissue egg load: The number of eggs per gram tissue (liver and intestine) was studied according to the procedure by Cheever (1968).

3- Oogram pattern: The percentages of immature, mature and dead ova in the small intestines were computed from a 


\section{Ibrahim Rabia et al}

total of 100 eggs per intestinal segment and classified according to the categories previously defined by Pellegrino et al. (1963).

\section{D- Histopathological Study:}

Liver specimens were fixed in 10\% buffered formalin and processed to prepare paraffin blocks. Paraffin sections $4 \mu \mathrm{m}$ thick were stained with haematoxylin-eosin and trichrome stains. The size of Schistosoma granulomas at $\mathrm{x} 10$ was measured per section using ocular micrometer. Only lobular granulomas containing egg in the center and confluent were measured. The mean diameter of granuloma per group was calculated according to Von Lichtenberg (1962).

\section{E- Immunological Parameters:}

\section{1- Enumeration of T-cell subsets:}

Fluorescein isothiocyanate (FITC)conjugated monoclonal antibodies for L3T4+ and Lyt2+ T-lymphocytes were used to determine the number of intralesional $\mathrm{T}$-cells in formalin fixed tissues, embedded in paraffin using a modified method of Swoveland and Ghonson (1979). Sections were treated according to histological procedures to remove paraffin and taken through several washes in graded alchohol to rehydrate the tissues. Slides were washed in $0.05 \mathrm{M}$ Tris buffer $(\mathrm{pH}$ 7.4), and incubated for $10 \mathrm{~min}$ in a humidified chamber after immersion in a solution of freshly prepared $1 \%$ trypsin. Slides were washed in $0.05 \mathrm{M}$ Tris buffer and distilled water. FITC-labeled L3T4+ (CD4+) and Lyt2+ (CD8+) antibodies diluted 1:1 in Tris buffer, $\mathrm{pH}$ 7.6, were used to stain two slides per mouse. Slides were incubated overnight with the monoclonal antibodies in a humidified chamber at $4^{\circ} \mathrm{C}$, washed in Tris buffer and mounted with entellan (Sigma) to enhance fluorescence prior to quantification. T-cells of each type were counted in two $50 \mathrm{~mm}$ wide bands perpendicular to each other in a single granuloma containing a single centrally positioned egg. The mean count per $50 \mathrm{~mm}$ band was obtained by dividing the sum of the two bands by two. A disaster Reichertjung fluorescent research micros- cope (Cambridge Instruments) objective 20X was used.

2- Detection of serum TNF-alpha and IFN-gamma by sandwich ELISA:

Serum murine TNF- and IFN- $\gamma$ levels were measured with an ELISA kit (Quantikine M, R\&D systems, Minneapolis, MN, USA). The detection limit of the assay was consistently $20 \mathrm{pg} / \mathrm{ml}$. The concentration was calculated from the standard curve that was performed in the same assay.

\section{Statistical analysis:}

Comparison was performed between the treated groups and untreated control. The percentage change between each two groups to be compared was assessed using the formula: Differences between the mean scores of any of the two groups to be compared were tested for significance, using an unpaired 2-tailed Student's t-test. The data were considered significant if $p$ values were less than 0.05 .

\section{Results}

The results in table (1) are showing significant reduction $(46 \%)$ in the mean number of $S$. mansoni adult worms in the group of infected mice immunized with purified eggs antigen compared to the infected controls $(\mathrm{P}<0.01$ ). Moreover, significant reduction in the mean number of ova / gram tissue (liver and intestine) was detected in the group immunized with purified egg antigen compared to infected controls $(\mathrm{P}<0.01)$. The percent of immature ova was less in the immunized group than the infected one while the percent of dead ova was higher (78.54) in the immunized group than the infected control $(\mathrm{P}<0.01)$.

\section{- Immunological Parameters: -}

\section{a- Enumeration of $T$ cell phenotypes in hepatic granuloma:}

In the SEP-Immunized infected group, the L3T4+ (CD4+) $\mathrm{T}$ cells significantly decreased $(\mathrm{p}<0.001)$ compared to the infected control group. However, Lyt2+ $(\mathrm{CD} 8+) \mathrm{T}$ cells were significantly increased $(\mathrm{p}<0.001)$ in the SEP-immunized group compared to infected control group. Also, there was a significant decrease in the 
ratio of $(\mathrm{CD} 4+/ \mathrm{CD} 8+)$ T-cells in the immunized infected group.

b- Detection of serum TNF-alpha and IFN-gamma by sandwich ELISA:

In the SEP-immunized infected group, the serum cytokine levels of both TNF- $\alpha$ and IFN- $\gamma$ were significantly decreased $(p<0.05)$ compared to the infected control groups.
Histopathological Parameters:

The mean granuloma diameter in infected control group was 390.34 \pm 0.49 while in SEP-immunized infected group, it was $340.22 \pm 0.22$, and the reduction in granuloma diameter was $12.84 \%$.

Photomicro graphs 1,2,3 showing control infected, immunized and uninfected immunized groups.

Table-1: Different parasitological parameters detected 8 weeks post-infection in animal groups.

\begin{tabular}{|c|c|c|c|c|c|c|}
\hline $\begin{array}{c}\text { Animal } \\
\text { groups }\end{array}$ & Worm Load & Hepatic ova & Intestinal Ova & $\begin{array}{c}\text { Oogram } \\
\text { Immature }\end{array}$ & $\begin{array}{c}\text { pattern } \\
\text { mature }\end{array}$ & $\begin{array}{c}\text { Dead } \\
\text { stage }\end{array}$ \\
\hline $\begin{array}{c}\text { Control } \\
\text { infected } \\
\text { group }\end{array}$ & $32.0 \pm 0.31$ & $8570.0 \pm 90.0$ & $18090 \pm 88.55$ & $45.2 \pm 0.22$ & $44.36 \pm 0.60$ & $10.44 \pm 0.1$ \\
\hline $\begin{array}{c}\text { Immunized } \\
\text { group (SEP) }\end{array}$ & $17.25 \pm 0.60^{*}$ & $4900.0 \pm 28.2^{*}$ & $8900.0 \pm 60.0^{*}$ & $37.1 \pm 0.33^{*}$ & $44.7 \pm 0.53$ & $18.2 \pm 1.0^{*}$ \\
\hline \% Reduction & $46 \%$ & $42.8 \%$ & $50.8 \%$ & $\begin{array}{c}\text { Reduction } \\
17.92 \%\end{array}$ & --------- & $\begin{array}{c}\text { Increased } \\
78.54 \%\end{array}$ \\
\hline
\end{tabular}

* Significant difference from infected control $(\mathrm{P}<0.01)$.

Table 2: Number of granuloma $T$ cell phenotypes per $50 \mu \mathrm{m}$ band (Mean \pm SEM) in the different studied groups.

\begin{tabular}{|l|l|l|l|}
\hline $\begin{array}{l}\text { Animal groups } \\
(\mathbf{n}=10)\end{array}$ & $\begin{array}{l}\text { CD4+ } \\
\text { Mean } \pm \text { SEM }\end{array}$ & $\begin{array}{l}\text { CD8+ } \\
\text { Mean } \pm \text { SEM }\end{array}$ & $\begin{array}{l}\text { CD4+/CD8+ } \\
\text { Mean } \pm \text { SEM }\end{array}$ \\
\hline Infected Control Group & $25.3 \pm 2.1$ & $9.2 \pm 1.4$ & $2.75 \pm 2.1$ \\
\hline $\begin{array}{l}\text { SEP-Immunized infected } \\
\text { Group }\end{array}$ & $14.2 \pm+1.9^{*}$ & $18.9 \pm 1.9^{*}$ & $0.75 \pm 1.8^{*}$ \\
\hline
\end{tabular}

$* p<0.001$ significant vs infected control group.

Table 3: Serum TNF- $\alpha$ and IFN- $\gamma$ levels against SEP of eggs in different studied groups.

\begin{tabular}{|l|c|c|}
\hline \multicolumn{1}{|c|}{$\begin{array}{c}\text { Animal Groups } \\
(\mathbf{n = 1 0 )}\end{array}$} & $\begin{array}{c}\text { TNF- } \boldsymbol{\alpha} \\
\text { Mean Pg/ml } \pm \text { SEM }\end{array}$ & $\begin{array}{c}\text { IFN- } \boldsymbol{\gamma} \\
\text { Mean Pg/ml } \pm \text { SEM }\end{array}$ \\
\hline Uninfected Control & $170 \pm 4.09$ & $277.7 \pm 4.48$ \\
\hline Immunized Group & $275 \pm 4.2$ & $510 \pm 5.4$ \\
\hline Infected Control Group & $565 \pm 25.3$ & $1105 \pm 35.2$ \\
\hline SEP-Immunized Group & $315 \pm 32.1^{*}$ & $950 \pm 49.2^{*}$ \\
\hline
\end{tabular}

$*_{p}<0.05$ significant vs infected control groups. 


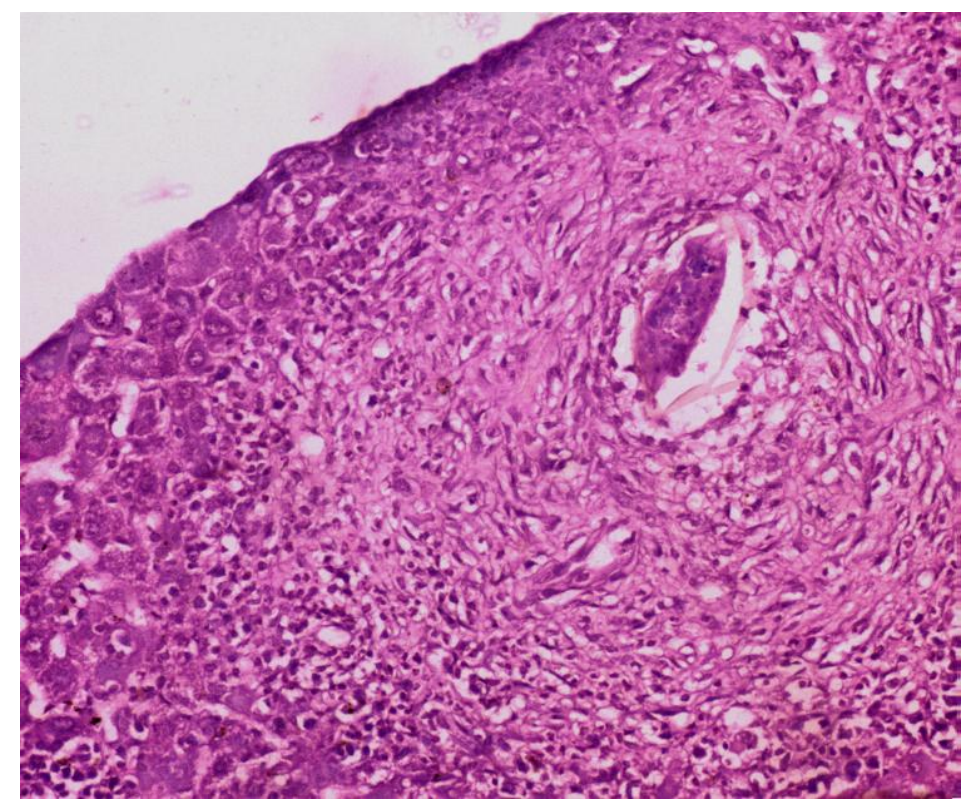

Fig (1) Photomicrograph showing Control infected group ,fibrocellular Granuloma intact mircidia.

( H\& E X200) .

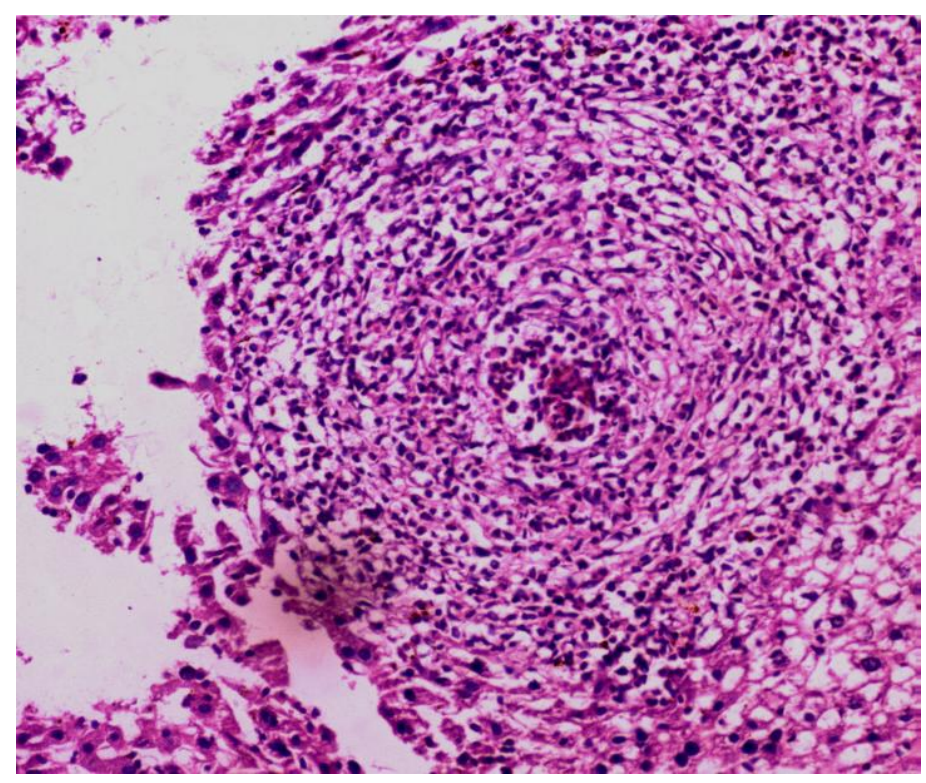

Fig (2) Photomicrograph showing Infected immunized group, fibrocellular granuloma surrounding degenerated ova with cellular inflteration lymphocytes and macrophages towards miracidia . ( H\& E X200) 


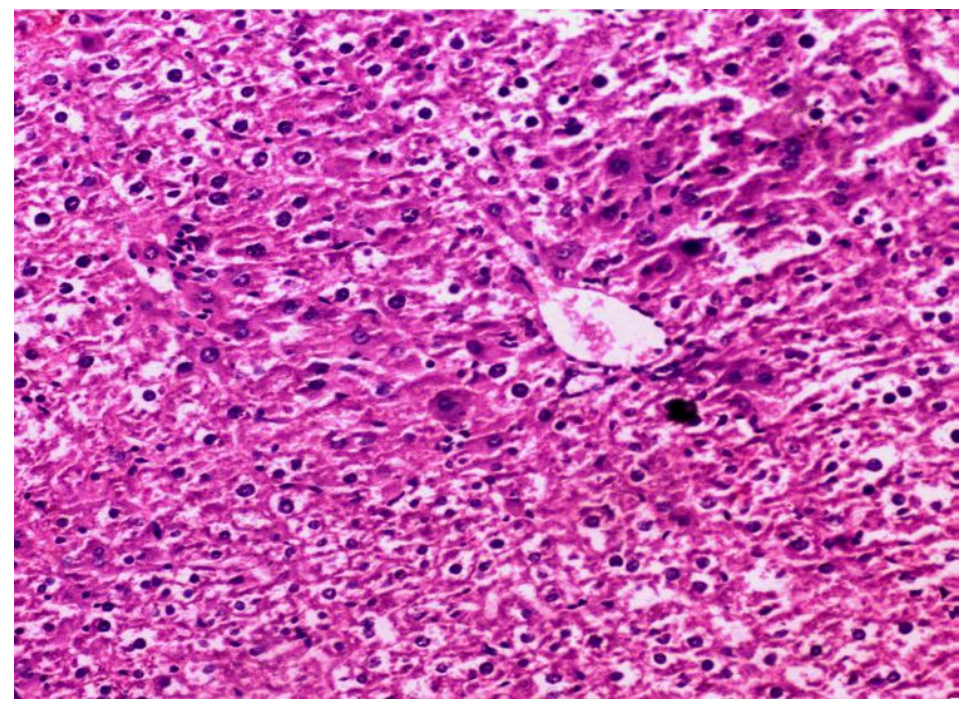

Fig (3) Photomicrograph showing Uninfected immunized group showing hydropic degeneration.

(H \& E x 200)

\section{Discussion}

The morbidity in schistosome infection is primarily due to fibrosis resulting in large part from healing of the inflammatory granulomatous focal damage around deposited eggs. This granulomatous reaction is most vigorous at the acute stage of infection (8-10 weeks post-infection), when $\mathrm{T}$ helper lymphocytes produce high levels of inflammatory lymphokines (Stadecker, 1992) and induces activation of granuloma macrophages (El-Ahwany et al., 2000). Some investigators indicated that, early in infection, probably even prior to egg production, schistosomes induce an immunologic environment that is highly conductive to the establishment of strong immunoregulatory mechanisms.

A lot of trials have been conducted to find a possible way for amelioration of the disease severity or morbidity by inhibition of host reaction around S.mansoni eggs. Schistosomal granuloma is mediated by class II MHC CD4+ $\mathrm{T}$ helper (Th) lymphocytes and is specifically directed to egg antigens (Zouain et al., 2002). The magnitude of schistosome granuloma depends upon the type of activated Th cell population in response to the quality and quantity of inducing antigen (Stadecker et al., 2001; Hanallah et al., 2003).

In the murine model, cells displaying different functions can be partially differentiated by cell surface phenotype markers such as CD4+ and CD8+ (Smith et al., 2004). In this work, phenotypic $\mathrm{T}$ cell subsets showed decrease in $\mathrm{CD} 4+/ \mathrm{CD} 8+\mathrm{T}$ cell ratio, in the SEP-immunized infected group compared to the corresponding infected control group. This finding was mainly due to an increase in the percentage of CD8+ subset in the SEP-immunized infected group. A shift in CD4+/CD8+ T cell ratio in favor of CD8+ lymphocytes in the circulation of chronically $S$. mansoni infected patients was reported by other investigators (Lukacs and Boros, 1993). The differences in $\mathrm{T}$ cell subset profile within the hepatic granuloma might be reflected by the functional activity of $\mathrm{T}$ cells. Thus, the reduction in granuloma diameter was concurrently associated with reduction in CD4+ cells and increase in CD8+ cells in SEP-immunized infected group. Although the decrease in granuloma diameter was not high, yet a marked increase in percent of degenerated ova was observed in SEP-treated infected group. In a study by Hassanein et al. (1997), they attributed hypo-responsiveness and decreased granuloma diameter to T-cell anergy following intravenous injection of SEA.

In this study, administration of SEP prior to infection resulted in decreased worm load, hepatic and intestinal ova together with change in Oogram pattern. This could be due to enhancement of 


\section{Ibrahim Rabia et al}

immune response. Similarly, immunization with SEP of lung stage schistosomula prior to infection induced protective effect, manifested by reduction in parasitological parameters, increased levels of specific immunoglobulins as well as raised hepatic m-RNA expression of TNF-alpha and TGFbeta (Maher et al., 2003). In the present work, at 8 weeks post infection the serum levels of IFN- $\gamma$ and TNF- $\alpha$ were significantly reduced compared to the infected controls, showing the most pronounced reduction of granuloma diameter. The cytokines play an important role in regulation of the inflammatory granulomatous response in schistosomiasis ( Garraud and Nutman, 1996). IFN- $\gamma$ and TNF- $\alpha$ appears to play an important role in the generation and maintenance of egginduced granuloma (Chensue et al., 1993 and Hoffman et al., 1998). The diminished focal and systemic production of IFN- $\gamma$ and TNF- $\alpha$ may be implicated in the downmodulation of the granulomatous response (Joseph and Boros, 1993 and Hassanein et al., 1999). In a studt by Singh et al., (2004), they reported that the decrease of the gene expression of TNF alpha and TGF-beta few months following successful treatment of $S$. mansoni infected mice, was correlated with resorption of liver fibrous tissue.

The development of hepatic fibrosis and portal hypertension is the principal cause of morbidity and mortality in schistosomiasis mansoni. Nevertheless, relatively little is known about the mechanisms that lead to excessive collagen deposition during infection with Schistosoma mansoni.

Our findings revealed that immunization with SEP of Schistosoma mansoni eggs induced some sort of protective effect manifested by, reduction in worm burden, egg load and granuloma size 8 weeks postinfection; the miracidia inside granulomas were mostly degenerated. This was accompanied by decreased ratio of $\mathrm{T}$ cell subsets $(\mathrm{CD} 4+/ \mathrm{CD} 8+)$ and decreased serum levels of both IFN- $\gamma$ and TNF- $\alpha$.

Further achievement trials concerned with immunization protocols against schistosomiasis are recommended helpfully to reach more promising results.

\section{References}

1. Asahi H, Oke T, Lopes da Rosa J, Williams DL, Stadecker MJ. (2003): sm-p25: A new egg component stimulating $\mathrm{T}$-cell and antibody responses in murine schistosome infection. Am. J. Trop. Med. Hyg., 69: 346.

2. Boros DL (1989): Immunopathology of Schistosoma mansoni infection. Clin. Microbiol. Rev., 2:250-269.

3. Botros S, Hassanein H, Hassan S, Akl M, Sakr S, Shaker Z, Hafez G, Ghorab N and Dean D (1995). Immunoregulatory potential of exogenous $S$. mansoni soluble egg antigen in a model of experimental in Schistosomiasis 1regulation of granuloma formation in vitro. Int.J. Immunopharmac., 12:707-718.

4. Bradford MM (1976): A rapid sensitive method for the quantization of microgram quantities of protein utilizing the principle of protein dye binding. Anal. Biochem ., 72: 248-254.

5. Cheever AW (1968): Condition affecting the accuracy of potassium hydroxide digestion technique for counting S.mansoni eggs in tissues. Bull wld Hlth Org., 39: 328-331.

6. Chensue SW, Warmington KS, Hershey SD, Terebuh PD, Othman $M$ and Kunkle $L$ (1993): Evolving T cell-response in murine schistosomiasis. $\mathrm{J}$ Immunol., 151: 1391-400.

7. Doenhoff M, Stanley RG, Curtis RHC and Pryce D (2003): A fibrinolytic enzyme in Schistosoma mansoni eggs. Am J Trop Med Hyg., 69: 347.

8. Duvall RH and Dewitt WB (1967): An improved perfusion technique for recov-ering adult Schistosoma from laboratory animals. Am. J. Trop. Med. Hyg., 16: 483- 4.

9. El- Ahwany EG, Hanallah SB ,Zada S,El-Ghorab N M,Badir B,Badawy A,Sharmy R,and Hassanein HI (2000): Immunolocalization of macrophage adhe-sion molecule-1 and macrophage inflamm-atory protein-1 in schistosomal soluble 
egg-induced granulomatous

hyporespons-iveness. Int $\mathrm{J}$ Parasitol., 30:837-84.

10. El- Ahwany EG, Nosseir M M and Aly I R (2006): Immunompulmonary and hepatic granulomatous response in mice immunized with purified lungstage schistosomulae antigen. J. Egypt. Soc. Parasitol., 36: 335350 .

11. Garraud O, Nutman TB (1996): The role of cytokines in human B-cell

different-iation into immunoglobulin secreting cells. Bull. Pasteur., 94: 285-309.

12. Hanallah SB,El-Lakkany N,Mahmoud S,Mousa $m$ and Botros S (2003): Altered immunoglobulin isotype profile and anti-immature worm surface immunoglobulins in mice harboring a praziquantel resistant Schistosoma mansoni isolate. APMIS, 111: 1125-1132.

13. Hassanein H, Akl M, Shaker Z, El-Baz H, Abo- Elala I, Rabia I, Sharmy $R$ and Doughty $B$ (1997): Induction of hepatic egg granuloma hypo responsiveness in murine schistosomtasis mansoni by intravenous injection of small doses of soluble egg antigen. APMIS. 105:77-83.

14. Hassanein H, Kamel M, Badawy A, El- Gorab N, Abdeen H, Zada S, El- Ahwany E and Doughty B (1999): Anti-miracidial effect of recombinant glutathione Stransferase 26 and soluble egg antigen on immune response in murine schistosomtasis mansoni. AMPIS, 107: 723-736.

15. Hoffmann KF, Caspar P, Cheever A.W. and Wynn TA (1998): IFN-gamma, Il-2 and TNF-alpha are required to maintain reduced liver pathology in mice vaccinated with Shistosoma mansoni eggs and IL2. J Immunol., 15: 4201-4210.

16. Jaton J, Brandt DC and Vassalli $P$ (1979): The isolation and characterization of immunoglobulins, antibodies and their constituent polypeptide chain. J. Immunol. Meth., 2: 4367.
17. Joseph AL and Boros DL (1993): Tumor necrosis factor plays a role in Schistosoma mansoni egg induced granulomatous inflammation. J. Immunol., 151: 5461-5471.

18. Maher K M, El- Shennawy A M, Ibrahim $\mathbf{R}$ B, Aly $\mathbf{E}$ and Mahmoud S (2003): Protective and antipathology potential of immunization with Schistosoma mansoni- secretory/ excretory product. New Egypt J Med ., 28: 173-182.

19. Mountfourd AP and Harrop $\mathbf{R}$ (1998): Vaccination against schistosomiasis: The case for lung -stage antigens. Parasitol. Today., 14: 109- 114.

20. Liang US, Bruce JI and Boyd DA (1987):Laboratory cultivation of Schist-osoma vector snails and maintenance of schistosome life cycle. Proceedings of the $1^{\text {st }}$ SinoAmercian Symposium, 1: 34-48.

21. Lightowlers MW and Rickard M D (1988): Excretory secretory products of hel-minthes parasites: Effects on the host imm-une responses. Parasitology. 96: 512366.

22. Pearce EJ, James SL, Hieny S, Lanar DE and Sher A (1988): Induction of protective immunity against $\mathrm{S}$. mansoni by vaccination with $S$. mansoni paramyosin (SM97), a non-surface parasite antigen. Proceedings of the National Academy of Science, USA. 74:5463-5467.

23. Pellegrino J, Oliveira CA, Faria J and Cumha AS (1962): New approach to the screening of drugs in experimental Schistosoma mansoni in mice. Am. J. Trop. Med. Hyg., 11: 201-215.

24. Singh KP, Gerard HC, Hudson AP, Boros DL. (2004): Expression of matrix metalloproteinases and their inhibitors during the resorption of schistosome egg-induced fibrosis in praziquantel-treated mice. Immunology. 111:343-52.

25. Smith $\mathbf{P}$, Walsh $\mathbf{C} \mathbf{M}$, Mangan $\mathbf{N}$ E, Fallon RE, Sayers JR, Mckenzie AN and Fallon PG (2004): Schistosoma mansoni worms induce anergy of T-cells via selective up-regulation of 


\section{Ibrahim Rabia et al}

programmed death ligand 1 on macrophages. J.Immunol., 173: 1240-1248.

26. Stadecker MJ (1992): The role of T-cell anergy in immunomodulation of schistosomiasis. Parasitol. Today, 8: 199204.

27. Stadecker MJ, Hernandez $\mathbf{H j}$ and Asahi H (2001): The identification and characterization of new immunogenic egg components: implications for evaluation and control of the immunopathologic T-cell response in schistosomiasis. Mem. Tnst. Oswaldo. Cruz., 96:29-33.

28. Swoveland $\mathbf{p}$ and Ghonson $\mathbf{K}$ (1979): Enhancement of florescent antibody staining of viral antigens in formalin fixed tissue by trypsin digestion, J. Infect. Dis., 140:458462.

29. Von Lichtenberg EV (1962):

Host response to eggs of

Schistosoma mansoni Granuloma formation in the unsensitized laboratory mouse. Am. J. Pathol., 41: 711 .

30. Wolwezuk C, Auriault H, GrasMass G, Vendeville J, Balloul M, Tartar A and Capron A (1989): Protective imm-unity in mice vaccinated with Schistosoma mansoni. J Immunol., 142: 13421350.

31. Wynn A (1999): Immune deviation as a strategy for schistosomtasis vaccines designated to prevent infection and egg induced

immunopathology.Microb.Infect.1

:525-534

32. Zouain CS, Gustavson S, SilvaTeixeira DN, Contigli C, Rodrigues V, Leite MF and Goes A M (2002): Human immune response in schistosomiasis: The role of P24 in the modulation of cellular reactivity to $S$. mansoni antigens. Hum Immunol., 63: 647- 656.

\section{دور الناتج الخارج من بيض البلهارسيا فى تقليل مضاعفات الكبد}

$$
\begin{aligned}
& \text { إبر اهيم ربيع - زينب فهمي - إيمان الأهو انى - هدى صبري } \\
& \text { قسم الطفيليات و المناعة بمعهد تيودر بلهارس ( الجيزة ـ القاهرة الئي ) }
\end{aligned}
$$

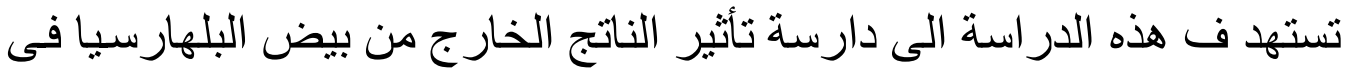

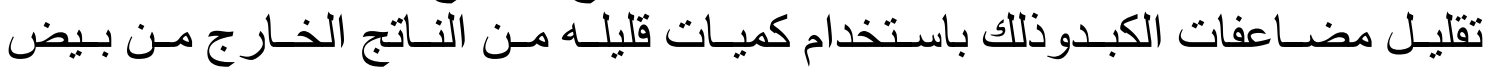

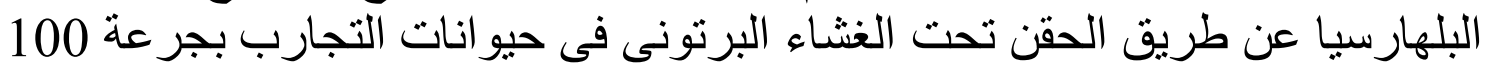

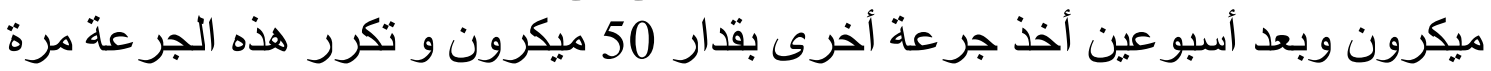

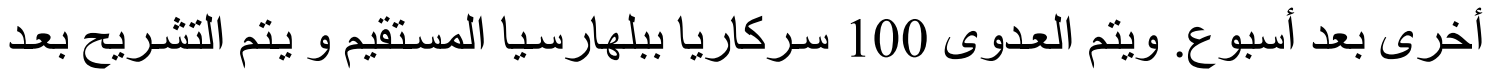
45 يوم.

وقد استخدمت ثلاثة مجمو عات من ذكور الفير أن البيضاء عمر 8 أسـابيع وزن

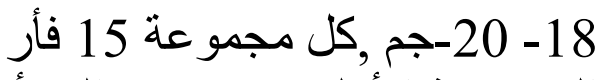

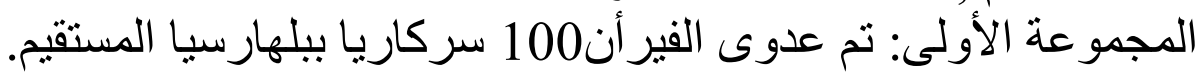

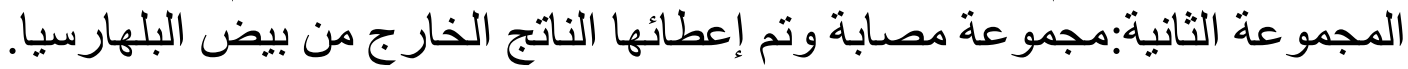

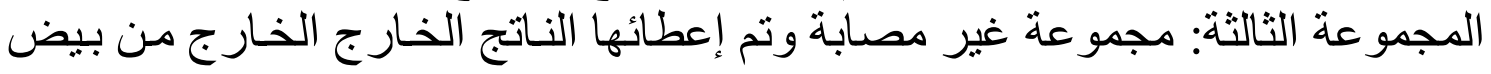


وقد أوضحت التجارب نقص فى CD4 \& CD8 فى المجموعة التى رفع منعتها نقص فى نسبه CD4\& CD8 ونقص فى TNF-alpha and IFN gamma. بالمقارنة بالمجمو عة المصابة فقط.

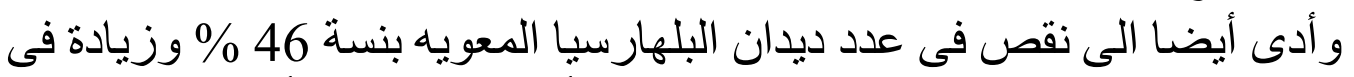
عدد البويضات الميتةو نقص فى عدد البويضات في أنسجة الكبد و الأمعاء ـ ـ و نقص النص فى حجم الورم الحبيى بنسة 12 \%

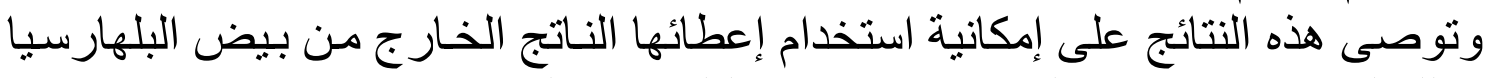
وذللك لنقص مضاعفات الكبد بعد الإصابة بالبلهارسيا المعوية . 